\title{
An Investigation of the Relationship Between the Carotid Intima-media Thickness and Trunk Control in the Acute Phase of Ischemic Cerebrovascular Disease
}

\author{
İskemik Serebrovasküler Hastalık Akut Döneminde Karotis İntima Media Kalınlığı ile \\ Gövde Kontrolü Arasındaki İlişkinin İncelenmesi
}

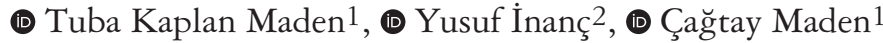 \\ ${ }^{1}$ Hasan Kalyoncu University Faculty of Health Sciences, Department of Physiotherapy and Rehabilitation, Gaziantep, Turkey \\ ${ }^{2}$ Gaziantep University Faculty of Medicine, Department of Neurology, Gaziantep, Turkey
}

\begin{abstract}
Objective: To investigate the relationship between the carotid intima-media thickness (tCIM) and trunk control in individuals in individuals who have the acute phase of ischemic cerebrovascular disease.

Materials and Methods: This study was conducted between January 2016 and January 2017 at the intensive care unit and Neurology Department of Gaziantep University. Thirty-one patients who had ischemic cerebrovascular disease within the last 72 hours were included in the study. tCIM was measured using portable ultrasound. The Trunk Impairment Scale (TIS) and Trunk Control Scale (TCS) were used for trunk assessment.

Results: It was demonstrated that there was no significant relationship between the TIS, TCS, and right and left tCIM measurements in any subjects (p>0.05). When the risk factors were investigated, it was found that hypertension was the leading risk factor with $30 \%$. A comparison of the subjects according to the affected side showed that there was no difference between trunk control, trunk impairment, and tCIM ( $>$ > 0.05 ).

Conclusion: There is no relationship between tCIM and trunk control. There is a need for further studies that investigate the relationship between functionality and risk factors.
\end{abstract}

Keywords: Trunk control, stroke, hemiplegia, carotid intima-media thickness

$\ddot{\mathbf{O z}}$

Amaç: İskemik serebrovasküler hastalık geçirmiş bireylerin akut döneminde karotis intima media kalınlı̆̆ı (tCIM) ile gövde kontrolü arasındaki ilişkinin incelenmesidir.

Gereç ve Yöntem: Bu çalışma Ocak 2016 ve Ocak 2017 tarihleri arasında, Gaziantep Üniversitesi Şahinbey Eğitim Araştırma ve Uygulama Hastanesi, Nöroloji servisinde ve yoğun bakımında gerçekleştirildi. Çalışmaya iskemik serebrovasküler hastalık geçirmiş ilk 72 saat süre içerisindeki 31 hasta dahil edildi. Bireylerin tCIM ölçümü taşınabilir ultrason ile yapıldı. Gövde değerlendirmesi için Gövde Bozukluk Ölçeği (GBÖ) ve Gövde Kontrol Ölçeği (GKO) yapıldı.

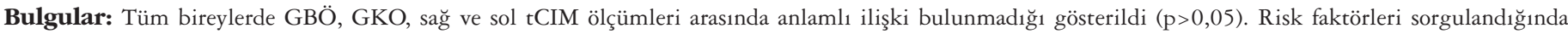
hipertansiyon \%30 oranla ilk sıradaydı. Etkilenen tarafa göre bireyler kıyaslandığında, bireylerin gövde kontrolü, gövde bozukluğu ve karotis intima media kalınlığı arasında fark olmadı $\breve{g} 1$ gözlendi $(\mathrm{p}>0,05)$.

Sonuç: tCIM ile gövde kontrolü arasındaki ilişki bulunmamaktadır. Fonksiyonellik ile risk faktöleri arasındaki ilişkiyi inceleyen çalışmalara ihtiyaç duyulmaktadır. Anahtar Kelimeler: Gövde kontrolü, inme, hemipleji, karotis intima-media kalınlığ 1

\section{Introduction}

Cerebrovascular disease (CVD) is one of the leading causes of mortality and morbidity globally (1). According to the World Health Organization, CVD is the second leading cause of death and it is of utmost importance in terms of public health because CVD treatment is expensive $(2,3)$.

The etiology of stroke involves many factors. Besides the non-modifiable risk factors such as age, sex and race, alcohol use and smoking, obesity, atherosclerosis, hypertension, diabetes

Address for Correspondence/Yazışma Adresi: Tuba Kaplan Maden PT, Hasan Kalyoncu University Faculty of Health Sciences,

Department of Physiotherapy and Rehabilitation, Gaziantep, Turkey

Phone: +90 5319340249 E-mail: tuba.kaplan@hku.edu.tr ORCID: orcid.org/0000-0001-8713-0825

Received/Geliş Tarihi: 25.09.2019 Accepted/Kabul Tarihi: 23.01.2020

${ }^{\oplus}$ Copyright 2020 by Turkish Neurological Society

Turkish Journal of Neurology published by Galenos Publishing House. 
mellitus, coronary artery diseases, peripheral artery diseases, and carotid intima-media thickness (tCIM) are risk factors for CVD $(4,5)$. It was shown that the therapeutic actions that particularly focus on the vascular risk factors to prevent secondary stroke decreased the risk of recurrent stroke in addition to the risk of other coronary or peripheral vascular attacks (5). Atherosclerotic plaques that affect the tCIM build up slowly and the first manifestation is fatty streaks in the intima (6). Therefore, early detection of atherosclerotic changes is vital. The most commonly used method of measuring tCIM is high-resolution ultrasonography (7). There is a strong correlation between the incidence of coronary artery diseases and stroke and tCIM measured with this method $(6,8)$.

Most studies focused on whether tCIM was a risk factor in different diseases or its relationship with other risk factors $(9,10)$. However, there are few studies in which tCIM is the outcome measure. Although several studies have investigated the effect of physical activity and regular exercise on tCIM, little is known about the relationship between tCIM and prognosis (11). Although previous studies on this subject reported that risk factors such as hypertension and smoking affected prognosis $(12,13)$, few studies have investigated the effects of inspiratory muscle training, which is known as risk factor on the prognosis in patients with stroke. Thus there is a need for studies investigating the effect of tCIM on prognosis.

The importance of evaluating trunk control in the early phase and the importance of the good state of trunk control in predicting the functional outcomes in patients with CVD have been demonstrated in recent studies $(14,15,16)$. This study, which assessed trunk control for prognosis, aimed to investigate the relationship between the tCIM and trunk control in individuals who were in the acute phase of ischemic CVD.

\section{Materials and Methods}

Approval to conduct this study was obtained from the Ethics Committee of Hasan Kalyoncu University for Non-Interventional Studies (decision no: 2016/03). The study was conducted between January 2016 and January 2017 at the intensive care unit and Neurology Department of Gaziantep University Sahinbey Training Research and Application Hospital.

Thirty-one patients aged 24-86 (65.74 15.50$)$ years (20 females and 11 males) were enrolled in the study. Patients who had an ischemic CVD within the last 72 hours, those who had a National Institute of Health score lower than 15, those who were allowed to sit from the hemodynamics aspect, and those who had no other neurologic or orthopedic problems were included in the study. Patients who were past the first 72 hours after admission to the ward and those who were not cooperative were excluded from the study.

Risk factors (age, sex, alcohol use and smoking, hypertension, heart disease, presence of diabetes) were evaluated and the tCIMs were measured by a physician. The Trunk Impairment Scale (TIS) and Trunk Control Scale (TCS) were used for trunk assessment by physiotherapists.

\section{Measurement of Carotid Intima-media Thickness}

The tCIM was measured using an A LOGIQ P5 portable ultrasonography device (GE Healthcare, Buckinghamshire, United Kingdom) with a scan frequency of 5-12 $\mathrm{MHz}$. The average thickness of three bilateral points was obtained using B-mode ultrasound.

\section{Trunk Impairment Scale}

The TIS is a valid and reliable test commonly used to assess trunk control after stroke. The highest score that can be obtained from the scale that evaluates the static balance, dynamic balance, and coordination is 16 . The scale was applied 24 hours after the cerebrovascular event by expert physiotherapists (17).

\section{Trunk Control Scale}

This is a scale obtained by modifying the scoring of the first clinical scale that was developed to evaluate trunk control. The scale consists of four items rated with three scores (0-12$25)$, wherein the maximum and minimum total scores are 100 and 0 , respectively (18). The test was applied 24 hours after the cerebrovascular event by expert physiotherapists.

\section{Statistical Analysis}

Statistical analyses were conducted using the Windows-based SPSS 22.0 (Statistical Package for the Social Sciences/IBM, SPSS Statistics for Windows, V.22.0) software package. In order to determine the sample size, statistical power analysis was conducted using $G^{*}$ Power version 3.1.9.2. The level of statistical significance was $\mathrm{p}<0.05$. The relationship between tCIM and trunk control was analyzed using Spearman's correlation coefficient. The MannWhitney $U$ test was used to compare trunk control and the independent t-test was used to compare tCIM between subjects with left and right hemiplegia.

\section{Results}

The study included 31 subjects $[20$ females $(65 \%)$ and 11 males $(35 \%)$ ] aged $24-86$ years. The mean age of the patients was $65.74 \pm 15.50$ years. Age, affected side, and sex distribution is provided in Table 1 for all subjects. The number of patients with left hemiplegia was higher than that of the patients with right hemiplegia.

It was demonstrated that there was no significant relationship between the TIS, TCS, and right and left tCIM measurements in any subjects (Table 2).

Hypertension was the leading risk factor (Table 3). According to the statistical analysis, risk factors did not affect trunk control.

Table 1. Demographic characteristics of the patients

\begin{tabular}{lll|} 
& Mean \pm SD & Minimum-maximum \\
Age (years) & $65.74 \pm 15.50$ & $24-86$ \\
& $\mathrm{n}$ & $\%$ \\
Sex & & \\
Female & 20 & 65 \\
Male & 11 & 35 \\
Affected side & & \\
Right & 12 & 39 \\
Left & 19 & 61 \\
SD: Standard deviation & & \\
\hline
\end{tabular}


A comparison of the subjects according to the affected side showed that there was no difference between trunk control, trunk impairment, and tCIM (p>0.05) (Table 4).

\section{Discussion}

This study has shown that there was no relationship between trunk control and tCIM in subjects who were in the acute phase of ischemic cerebrovascular attack. In a previous study, it was reported that tCIM values higher than $1.7 \mathrm{~mm}$ could be described as a risk factor (19). The tCIM values measured in the present study were not high enough to constitute a risk factor. However, another study reported that the plaque structures and disruptions in these plaque structures had an important role in explaining the relationship between tCIM and stroke (20). In a study by İnanç et al. (1), it was reported that there was a correlation between tCIM and the incidence of stroke. Although García et al. (21) demonstrated that tCIM was not an indicator of atherosclerosis in patients with stroke, it was proven in another study investigating the relationship between gait speed and tCIM, which is accepted as a risk factor, that there was a correlation between tCIM and balance and walking performance in the elderly (22). We believe that thickness measurements were not enough and plaque structures should also be examined in this study investigating the relationship between tCIM and functionality.

Park et al. (23) indicated that carotis plaque counts affected outcomes after long-term follow-up of patients with ischemic stroke. In a study investigating the effect of tCIM on prognosis in small deep brain infarcts that included two different vascular pathologies, it was demonstrated that the relationship according to the place of effect (24). Futhermore, the same study demonstrated that tCIM was an independent factor. In our study, even though the total plaque number was not counted, it was determined

Table 2. The relationship between trunk impairment scale, trunk control test and right and left carotid intima-media thickness measurements

\begin{tabular}{|c|c|c|c|c|}
\hline & $\begin{array}{l}\text { Trunk impairment } \\
\text { scale } \\
\text { r (p) }\end{array}$ & $\begin{array}{l}\text { Trunk } \\
\text { control scale } \\
\text { r (p) }\end{array}$ & $\begin{array}{l}\text { tCIM-right } \\
\text { r (p) }\end{array}$ & $\begin{array}{l}\text { tCIM-left } \\
\mathrm{r}(\mathrm{p})\end{array}$ \\
\hline Trunk & - & $0.713(<0.001)^{*}$ & -0.326 & -0.255 \\
\hline Impairment & & & $(0.073)$ & $(0.166)$ \\
\hline \multicolumn{5}{|l|}{ Scale } \\
\hline \multirow[t]{2}{*}{ tCIM-right } & -0.326 & $-0.113(0.545)$ & - & 0.921 \\
\hline & $(0.073)$ & & & $(<0.001)^{*}$ \\
\hline \multirow[t]{2}{*}{ tCIM-left } & -0.255 & $-0.121(0.515)$ & 0.921 & - \\
\hline & $(0.166)$ & & $(<0.001)^{*}$ & \\
\hline
\end{tabular}

Table 3. Distribution of the risk factors

\begin{tabular}{lll|}
\hline None & n & $\%$ \\
Hypertension & 12 & 26 \\
Heart diseases & 14 & 30 \\
Diabetes & 10 & 22 \\
Smoking/alcohol consumption & 7 & 15 \\
\hline
\end{tabular}

Table 4. Trunk control test, trunk impairment scale and carotid intima-media thickness measurement results according to the affected side

\begin{tabular}{|c|c|c|c|c|}
\hline & $\begin{array}{l}\text { Subjects with right hemiplegia } \\
\text { mean } \pm S D\end{array}$ & $\begin{array}{l}\text { Subjects with left hemiplegia } \\
\text { mean } \pm \text { SD }\end{array}$ & $z-t$ & $\mathrm{p}$ \\
\hline Trunk Impairment Scale ${ }^{1}$ & $14.08 \pm 5.14$ & $9.89 \pm 7.80$ & 1.52 & 0.126 \\
\hline Trunk Control Scale ${ }^{1}$ & $80.91 \pm 27.68$ & $60.57 \pm 33.96$ & 1.84 & 0.066 \\
\hline tCIM-right $^{2}$ & $0.30 \pm 0.57$ & $0.64 \pm 0.73$ & 1.44 & 0.159 \\
\hline tCIM-left ${ }^{2}$ & $0.34 \pm 0.67$ & $0.59 \pm 0.69$ & 0.99 & 0.328 \\
\hline
\end{tabular}


that tCIM was an independent factor. This study investigating the effect of tCIM on prognosis in a Turkish sample was original because the effect of tCIM, which is recognized as a risk factor, on prognosis has not been investigated up to date.

A good trunk position sense and trunk control are necessary for functionality, which is the main goal of rehabilitation. Trunk control ensures independence in daily life activities and proper movement of the limbs (25). A study investigating the relationship between trunk control and lower limb motor function improvement showed that trunk control and balance were negatively affected by disruptions in postural stability after stroke (17). Numerous studies have demonstrated that there is a strong correlation between functionality and trunk control $(25,26,27)$. It was shown that there was a strong correlation between trunk control and the length of hospital stay and functional independence measure in hemiparetic patients (15). In our study, TCS were used as functional independence measures since trunk control affects the balance, gait and limb movements.

Tanovic investigated the effects of the risk factors on treatment in patients with stroke and found that diabetes and hypertension had a negative impact on treatment (12). Individuals with hypertension have a lower level of independence in their daily lives than normotensive individuals because they have more complex complications more frequently (28). According to another study based on the analysis of data obtained from 2,000 patients, the most common risk factor was hypertension, which is similar to the findings of our study, and the patients' level of independence was not affected in the long term (29). There are numerous modifiable and non-modifiable risk factors for stroke and we investigated the most common risk factors in our study. A previous study has shown that the patients with chronic diabetes had increased risk of atherosclerosis, cardiovascular disease, and ischemic CVD (30). It was also found in another study comparing young individuals with and without diabetes that the rehabilitation process was negatively affected in individuals with diabetes (31). The third most common factor after hypertension and diabetes is smoking, which is known to have a negative impact on rehabilitation outcomes in patients with stroke (13). However, risk factors did not have an impact on trunk control, which was used to indicate the state of functional independence in our study. We believe that this result was obtained due to the low number of patients.

According to our study, trunk control did not change depending on the affected side. Although trunk control impairment due to one-sided neglect, asymmetrical weight shift, reduced or delayed postural adjustments, muscle coactivation and abnormal pelvic tilt were more commonly observed particularly when the right hemisphere was affected (32), there are also studies showing that patients who have an affected right hemisphere had normal axial movements and that an existing control impairment could not be directly attributed to a lesion in the right hemisphere. Trunk apraxia was also observed in the presence of lesions in the left hemisphere, which is responsible for planning axial movements, through aphasia and ideomotor apraxia (33). This study confirmed our thought that symptoms such as aphasia, apraxia, and body image disorders associated with the affected hemisphere had an impact on trunk control. In addition, it was shown in previous studies that trunk control was associated with balance and trunk muscle strength $(34,35)$. A study comparing subjects with right and left hemiplegia in terms of balance in the chronic phase showed that the subjects with left hemiplegia had poorer balance (36). In this current study, we evaluated trunk control in the acute phase and it is considered that there was no difference between the subjects with right and left hemiplegia in terms of trunk control because the characteristic symptoms for right and left hemiplegia are not well-established. We are of the opinion that comparing trunk control in patients with hemiplegia according to the affected hemisphere in the early and late phase would contribute to the literature.

\section{Study Limitations}

The limitations of the present study were plaque structures that were formed on the carotid intima-media layer were not evaluated, the risk factors could not be evaluated in more detail, and other scales such as Rivermead motor assessment were not used for motor evaluation.

\section{Conclusion}

There was no significant relationship between tCIM, which is accepted as a risk factor for cardiovascular diseases, and trunk control, which is used as a measure of independence. It is considered that it is necessary to conduct further studies that compare tCIM as well as plaque structures according to the different hemispheres affected.

\section{Ethics}

Ethics Committee Approval: Ethical approval was obtained from the Ethics Committee of Kalyoncu University for NonInterventional Studies (decision no: 2016/03). The study protocol was performed in accordance with the Declaration of Helsinki.

Informed Consent: Written informed consent was obtained from the participants.

Peer-review: Externally and internally peer-reviewed.

\section{Authorship Contributions}

Concept: T.K.M., Y.İ., Ç.M., Design: T.K.M., Y.İ., Data Collection or Processing: T.K.M., Y.I., Ç.M., Analysis or Interpretation: T.K.M., Ç.M., Literature Search: T.K.M., Y.İ, Writing: T.K.M.

Conflict of Interest: No conflict of interest was declared by the authors.

Financial Disclosure: The authors declared that this study received no financial support.

\section{References}

1. İnanç Y, İnanç Y. Relationship between hematologic parameters and carotid intima media thickness in patients with acute stroke. Turk J Cerebrovasc Dis 2018;24:71-77.

2. Word Health Organization (WHO). Erişim Tarihi: 24 Temmuz 2019. Available from: http://origin.who.int/gho/mortality_burden_disease/en/

3. Thrift AG, Thayabaranathan T, Howard G, et al. Global stroke statistics. Int J Stroke 2017;12:13-32.

4. Palm F, Urbanek C, Wolf J, et al. Etiology, risk factors and sex differences in ischemic stroke in the Ludwigshafen Stroke Study, a population-based stroke registry. Cerebrovasc Dis 2012;33:69-75.

5. Arboix A. Cardiovascular risk factors for acute stroke: Risk profiles in the different subtypes of ischemic stroke. World J Clin Cases 2015;3:418.

6. Alagöz D, Coşkun ZÜ, Yılmaz C. Tıkayıcı tip serebrovaskuler hastalıkların karotis intima-media kalınlı̆̆ $\breve{1}_{1}$ ile ilişkisi. Eur Arc Med Res 2013;29:3743. 
7. Stein JH, Korcarz CE, Hurst RT, et al. Use of carotid ultrasound to identify subclinical vascular disease and evaluate cardiovascular disease risk: a consensus statement from the American Society of Echocardiography carotid intima-media thickness task force endorsed by the society for vascular medicine. J Am Soc Echocardiogr 2008;21:93-111.

8. Pursnani S, Diener-West M, Sharrett AR. The effect of aging on the association between coronary heart disease risk factors and carotid intima media thickness: an analysis of the Atherosclerosis Risk in Communities (ARIC) cohort. Atherosclerosis 2014;233:441-446.

9. Tutoğlu A, Boyaci A, Boyaci N,et al. Is there any relationship between joint destruction and carotid intima-media thickness in patients with rheumatoid arthritis? J Phys Ther Sci 2014;26:1093-1096.

10. Koskinen J, Magnussen CG, Sinaiko A, et al. Childhood age and associations between childhood metabolic syndrome and adult risk for metabolic syndrome, type 2 diabetes mellitus and carotid intima media thickness: the International childhood cardiovascular cohort consortium. J Am Heart Assoc 2017;6:e005632.

11. Park JH, Park H, Lim ST, Park JK. Effects of a 12-week healthy-life exercise program on oxidized low-density lipoprotein cholesterol and carotid intimamedia thickness in obese elderly women. J Phys Ther Sci 2015;27:14351439.

12. Tanovic E, Selimovic S, Tanovic H. Assessment of the effects of rehabilitation after cerebrovascular accident in patients with diabetes mellitus and hypertension as risk factors. Med Arch 2014;68:124.

13. Selimović S, Tanović E, Tanović H, Miladinović K. The effect of smoking on the results of rehabilitation in patients after cerebrovascular accident. Med J 2014;20.

14. Kim TJ, Seo KM, Kim DK, Kang SH. The relationship between initial trunk performances and functional prognosis in patients with stroke. Ann Rehabil Med 2015;39:66-73.

15. Duarte E, Marco E, Muniesa J, et al. Trunk control test as a functional predictor in stroke patients. J Rehabil Med 2002;34:267-272.

16. Raine S, Meadows L, Lynch-Ellerington M. Bobath concept- theory and practice in neurologic rehabilitation. 1st ed. United Kingdom: Willey and Blackwell, 2009.

17. Karthikbabu S, Chakrapani M, Ganesan S, Ellajosyla R. Pelvic alignment in standing, and its relationship with trunk control and motor recovery of lower limb after stroke. Neurol Clin Neurosci 2017;5:22-28.

18. Verheyden G, Nieuwboer A, Van de Winckel A, De Weerdt W. Clinical tools to measure trunk performance after stroke: a systematic review of the literature. Clin Rehabil 2007;21:387-394.

19. Kokubo Y, Watanabe M, Higashiyama A, et al. Impact of intima-media thickness progression in the common carotid arteries on the risk of incident cardiovascular disease in the suita study. J Am Heart Assoc 2018;7:e007720.

20. Polak JF, Pencina MJ, O'leary DH, D’agostino RB. Common carotid artery intima-media thickness progression as a predictor of stroke in multi-ethnic study of atherosclerosis. Stroke 2011;42:3017-3021.
21. García JG, Roquer J, Serena J, et al. Carotid intima-media thickness is not associated with markers of atherosclerosis in stroke patients. J Stroke Cerebrovasc Dis 2016;25:1070-1075.

22. Elbaz A, Ripert M, Tavernier B, et al. Common carotid artery intima-media thickness, carotid plaques, and walking speed. Stroke 2005;36:2198-2202.

23. Park H, Han M, Kim YD, et al. Impact of the total number of carotid plaques on the outcome of ischemic stroke patients with atrial fibrillation. J Clin Med 2019;8:1897.

24. Duan S, Zhang S, Li L, Ren C, Xie J. Carotid artery intima-media thickness associated with prognosis of intracranial branch atheromatous disease. Int J Neurosci 2017;127:361-367.

25. Likhi M, Jidesh V, Kanagaraj R, George JK. Does trunk, arm, or leg control correlate best with overall function in stroke subjects? Top Stroke Rehabil 2013;20:62-67.

26. Wang CH, Hsueh IP, Sheu CF, Hsieh CL. Discriminative, predictive, and evaluative properties of a trunk control measure in patients with stroke. Physical therapy 2005;85:887-894.

27. Curtis DJ, Butler P, Saavedra S, et al. The central role of trunk control in the gross motor function of children with cerebral palsy: a retrospective crosssectional study. Dev Med Child Neurol 2015;57:351-357.

28. Tanović E, Tanović H. Functional electric stimulation on walking rehabilitation on patients with hemiplegia after stroke. Neurol Croat 2007;56(Suppl 1):188-194.

29. Karatepe AG, Kaya T, Sen N, Günaydin R, Gedizlioglu M. The risk factors in patients with stroke and relations with functional independence. Turk J Phys Med Rehab 2007;53:89-93.

30. Dorndorf W, Marx P. Stroke Prevention. In: Caplan LR (ed). 4th ed. Philadelphia: Sounders Elsevier, 2009:581-592.

31. Piernik-Yoder B, Ketchum N. Rehabilitation outcomes of stroke patients with and without diabetes. Arch Phys Med Rehabil 2013;94:1508-1512.

32. Tasseel-Ponche S, Yelnik A, Bonan I. Motor strategies of postural control after hemispheric stroke. Neurophysiol Clin 2015;45:327-333.

33. Spinazzola L, Cubelli R, Della Sala S. Impairments of trunk movements following left or right hemisphere lesions: dissociation between apraxic errors and postural instability. Brain 2003;126:2656-2666.

34. Collin C, Wade D. Assessing motor impairment after stroke: a pilot reliability study. J Neurol Neurosurg Psychiatry Res 1990;53:576-579.

35. Yeşilyurt $\mathrm{S}$. Toplumda yaşayan kronik hemiplejik hastalarda üst ekstremite fonksiyonları ve gövde kontrolü ile düşme, düşme korkusu, denge ve yaşam kalitesi arasındaki ilişki (Doktora Tezi) Konya: Selçuk Üniversitesi Tıp Fakültesi; 2010.

36. Ünal A. Sağ ve sol hemisfer lezyonu olan hemiparetik bireylerde dengenin karşılaştırılması (Yüksek Lisans Tezi) Denizli: Pamukkale Üniversitesi; 2014. 